\title{
Determination of Metabolizable Energy Value of Corn with Different Average Geometric Diameters for European Quails (Coturnix coturnix coturnix)
}

\author{
Marcelo José de Mello Rezende ${ }^{1 *}$, Alessandro Figueiredo Torres ${ }^{2}$, Luci Sayori Murata ${ }^{1}$, \\ José Américo Soares Garcia ${ }^{1}$ and Concepta Margaret McManus ${ }^{1}$ \\ ${ }^{1}$ Faculdade de Agronomia e Veterinária; Universidade de Brasília; Campus Darcy Ribeiro; 70910-900; Brasília - \\ DF- Brasil. ${ }^{2}$ Ministério da Agricultura Pecuária e Abastecimento; 70043-900; Brasília - DF- Brasil
}

\begin{abstract}
Metabolizable energy (ME) of corn with different geometric diameters was determined in European quail with 26 days of age with $124 \mathrm{~g}$ of mean live weight, using the Total Collection of Excreta Method. One hundred and twenty five quails were divided in five treatments, five replications with five quails each, with one treatment used to determine endogenous losses. Values of Average Geometric Diameter (AGD) of the corn were 600, 800, 1000 and $1200 \mu \mathrm{m}$. ME of corn was not affected by AGD. Average values were 3079, 3274, 3300, $3137 \mathrm{Kcal} / \mathrm{kg}$ respectively for apparent metabolizable energy, corrected apparent metabolizable energy, true metabolizable energy, corrected true metabolizable energy.
\end{abstract}

Key word: metabolizable apparent energy, metabolizable true energy, particle size, total collections of excreta.

\section{INTRODUCTION}

Corn makes up approximately 60 to $70 \%$ of poultry feed formularizations, having a considerable effect on the total cost of production. Therefore, the knowledge of the energy value and possible ways to reduce cost, such as in the milling process, can help in optimizing production.

The production of European quails (Coturnix coturnix coturnix) has assumed world-wide importance in recent years, not only for its use in laboratories for avian research, but also commercial exploration for meat and egg production (Shirivastav, 2002). According to this author, to obtain maximum benefit in quail production, the supply of balanced diets are necessary to reduce costs and to supply all nutrients necessary in the proper ratios for optimum growth and production.

However, quail nutritional requirements are not known with the same precision as for commercial hens. The recommendations used for quails in countries with temperate climates cannot be directly applied to tropical countries. Blair et al. (1983) showed significant differences between nutritional requirements for hens in different regions of the world.

The metabolizable energy (ME) requirements for quails vary considerably among authors. According to NRC (1994), the recommendation is

\footnotetext{
* Author for correspondence: mrezende@unb.br
} 
of $3138 \mathrm{Kcal} / \mathrm{kg}$ of ME for birds in growth and laying. Lepore and Marks (1971), cited by Shrivastav (2002), recommended for the initial and growth phases, values of 2600 and $2851 \mathrm{Kcal} / \mathrm{kg}$, respectively. A study developed with a quail strain selected for meat indicated a requirement of 2801 $\mathrm{Kcal} / \mathrm{kg}$ of ME approximately (Shrivastav, 1990). The present work was carried out to determine the ME value of corn with different average geometric diameters (AGD), through the method of total collection of excreta in European quails (Coturnix coturnix coturnix).

\section{MATERIAL AND METHODS}

The experiment was carried out at dependences of the Veterinary Hospital of the University of Brasilia (UnB). The Total Collection of Excreta Method was used. One hundred and twenty five 26 day old female quails with $124 \mathrm{~g}$ mean live weight were assigned in a completely randomized design to five treatments; with one group for the determination of endogenous losses. Five replications and five quails per experimental unit were used.

The experimental period was nine days, four days for adaptation to experimental diets and five days for the collection of excreta. Experimental diets were formulated in accordance with NRC (1994). The reference diet was used based on corn and soybean meal (Table 1), with the corn AGD (600, 800,1000 and $1200 \mu \mathrm{m}$ ) beig the only source of variation. The AGD value of corn was taken after grinding and sifting, to attain desired AGD according to Zanotto et al. (1998).

A tray covered with plastic was installed under each cage to collect the excreted material during the experimental period. To determine the endogenous losses, the quails were fasted for $24 \mathrm{~h}$. After this period the excreteted material was collected during a $48 \mathrm{~h}$ period.

Table 1 - Composition of reference diet.

\begin{tabular}{lc}
\hline Ingredient & $\%$ \\
\hline Corn & 60.65 \\
Soybean meal & 35.10 \\
Dicalcium phosphate & 1.70 \\
Salt & 0.40 \\
DL-methionine & 0.20 \\
L-lysine & 0.05 \\
Limestone & 1.30 \\
Mineral and vitamin mixture & 0.60 \\
\hline Calculated nutrient content & 21.00 \\
\hline Protein (\%) & 2900 \\
Metabolizable Energy (kcal/Kg) & 1.00 \\
Calcium (\%) & 0.42 \\
Available phosphorus (\%) & 0.85 \\
Methionine+Cystine (\%) & 1.15 \\
Lysine (\%) & \\
'Supplied per kilogram of diet: 25000 mg (manganese), 23330 mg (zinc), 16670 mg (iron), 2570 mg (cooper), 250 mg (iodine), \\
(100 mg (selenium), 2666570 UI (vitamin A), 666670 UI (vitamin D3), 5000 mg (vitamin E), 600 mg (vitamin K3), 600 mg \\
(vitamin B1), 2000 mg (vitamin B2), 933 mg (vitamin B6), 4000 mcg (vitamin B12), 333 mg (folic acid), 20 mg (Biotin), 5000 \\
mg (acid pantothenic), 33,33 g (Antioxidant), 19g (Growth Promoter), 4 g (Gencian Violet).
\end{tabular}

Diets were offered ad libitum during the whole period of excreta collection. The ration was weighed before and after it was supplied, to determine consumption. Collections were carried out twice a day between 6 am and $6 \mathrm{pm}$. The excreta were collected individually in replicate, weighed and stored in plastic bags. Later, the material was frozen until processing.

The samples of excreta were homogeneized, a sample of each replicates taken and dried at $55^{\circ} \mathrm{C}$ for $16 \mathrm{~h}$ by pre-heating and tests conducted to determine the Dry Matter (DM), Ether Extract (EE) and Crude Fiber (FB) content according to Silva (2002). Crude energy was determined using a PARR calorimeter. Values of Apparent Metabolizable Energy (AME) were calculated on the basis of analysis of results using the equations proposed by Matterson et al., (1965) and adjusted for the nitrogen retention, in accordance with the formula cited by Albino (1991). 
The statistical analyses of data were carried out using Statistical Analyses System Program (SAS, 2000). The averages were then compared using Tukey's Test $(\mathrm{P}<0.05)$.

\section{RESULTS AND DISCUSSION}

The corn showed $8.13 \%$ Crude Protein (CP), 4.53\% Ether Extract, $2.50 \%$ Crude Fiber (CF), 85.44\% Dry Matter (DM) and $3920 \mathrm{Kcal} / \mathrm{kg}$ Crude Energy (CE).

The means of CP, DM and CE of corn were lower than those presented by Rostagno (2005). However, the values of $\mathrm{EE}$ and $\mathrm{CF}$ were higher than those presented by the same author. This variation may be due to climate, soil, genetic variety of corn, fertilization used and corn processing.

Values of corn ME with different AGD, are presented in Table 2. The means of apparent metabolizable energy (AME) of the corn varied from 2950 to $3268 \mathrm{Kcal} / \mathrm{kg}$, and was inferior to those found by Furlan (1998) and Vilar da Silva (2003) who observed means of 3444 and 3340 $\mathrm{Kcal} / \mathrm{kg}$ for Japanese quails, respectively. However, for the corrected apparent metabolizable energy (AMEn), the variation of values was from 3165 to $3445 \mathrm{Kcal} / \mathrm{kg}$, close to those found by Furlan (1998) (3429 Kcal/kg). This difference may be explained by older quails (65 day old) used in that study. Rodrigues (2001) found values of AMEn that varied between 3028 and $3529 \mathrm{Kcal} / \mathrm{kg}$ for roosters and between 3419 and $3573 \mathrm{Kcal} / \mathrm{kg}$ for chickens, indicating variation between categories of birds.

Table 2 - Mean metabolizable energy value of corn with different average geometric diameters.

\begin{tabular}{ccccc}
\hline AGD $(\boldsymbol{\mu m})$ & AME $(\mathbf{K c a l} / \mathbf{k g})$ & AMEn $(\mathbf{k c a l} / \mathbf{k g})$ & TME $(\mathbf{K c a l} / \mathbf{k g})$ & TMEn $(\mathbf{K c a l} / \mathbf{k g})$ \\
\hline 600 & $2950 \pm 203$ & $3215 \pm 181$ & $3170 \pm 185$ & $3079 \pm 192$ \\
800 & $2972 \pm 206$ & $3165 \pm 237$ & $3214 \pm 292$ & $3014 \pm 221$ \\
1000 & $3128 \pm 593$ & $3274 \pm 517$ & $3338 \pm 577$ & $3144 \pm 528$ \\
1200 & $3268 \pm 133$ & $3445 \pm 117$ & $3480 \pm 149$ & $3313 \pm 109$ \\
\hline
\end{tabular}

Means in the same column did not differ statistically $(\mathrm{P}<0.05)$. AME=apparent metabolizable energy, AGD= average geometric diameter, $\mathrm{AMEn}=$ corrected metabolizable energy, TME=true metabolizable energy, TMEn= corrected metabolizable energy.

TME values varied from 3170 to $3480 \mathrm{Kcal} / \mathrm{kg}$ for corn with 600 and $1200 \mu \mathrm{m}$ of AGD, respectively. TMEn in this case varied between 3014 and 3313 $\mathrm{Kcal} / \mathrm{kg}$. These values are close to those of Nascimento (1998), who found $3340 \mathrm{Kcal} / \mathrm{kg}$ for TME when working with a Total Collection of Excreta in chickens of 23 days of age.

The results found here was lower than those found by Junior (1998) who worked with forced feeding methodology in cecotomized roosters, and found 4094 and $3937 \mathrm{Kcal} / \mathrm{kg}$ for TME and TMEn, respectively. These higher values may be explained by the fact that the author worked with adult animals that used the energy in foods more efficiently than young animals.

The size of corn particles did not modify $(\mathrm{P}>0.05)$ the ingestion and excretion of dry matter (Table 3 ). The mean consumption of dry matter (DM) obtained were $481,465,489$ and $488 \mathrm{~g}$, and excretion of DM were 125, 116, 120 and $119 \mathrm{~g}$ for diets with AGD of $600,800,1000$ and $1200 \mu \mathrm{m}$, respectively. European quails in this study presented a dry matter digestibility coefficient (DMDC) between 74.01 and $75.61 \%$.

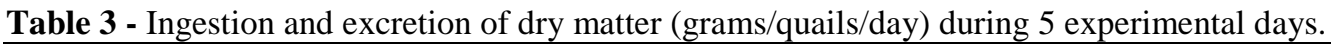

\begin{tabular}{cccc}
\hline AGD $(\boldsymbol{\mu m})$ & DM consumption $(\mathbf{g})$ & DM excretion $(\mathbf{g})$ & DMDC $(\boldsymbol{\%})$ \\
\hline 600 & 19.2 & 5.0 & 74.01 \\
800 & 18.6 & 4.7 & 75.05 \\
1000 & 19.6 & 4.8 & 75.46 \\
1200 & 19.5 & 4.8 & 75.61 \\
\hline
\end{tabular}

Means in the same column did not differ statistically $(\mathrm{P}<0,05)$. AGD=average geometric diameter. $\mathrm{DM}=$ dry matter. $\mathrm{DMDC}=\mathrm{dry}$ matter digestibility coeficient. 


\section{CONCLUSION}

Different average geometric diameters of corn may be used in the quail's diet formulation without modifying food intake and digestibility. Thus, among studied AGD, the cheapest should be used.

The variation observed in the metabolizable energy values of corn suggested that new studies should be carried out aiming at a better standardization of corn energy value for European quails.

Determinação dos Valores de Energia Metabolizável do Milho com Diferentes Diâmetros Geométrico Médio para Codornas Européias

\section{RESUMO}

Determinou-se o valor de energia metabolizável (EM) do milho com diferentes diâmetros geométrico médio em codornas com 26 dias de idade e $124 \mathrm{~g}$ de peso médio, utilizando-se a metodologia da coleta total de excretas. Foram utilizadas 125 codornas distribuídas em cinco tratamentos com cinco repetições de cinco aves, sendo um tratamento para determinar as perdas endógenas. Os valores de diâmetro geométrico médio (DGM) do milho estudado foram 600, 800, 1000 e $1200 \mu \mathrm{m}$. O DGM não apresentou influência significativa sobre a EM do milho que apresentou valores médios de 3079, 3274, 3300, $3137 \mathrm{Kcal} / \mathrm{kg}$, respectivamente, para energia metabolizável aparente, energia metabolizável aparente corrigida, energia metabolizável verdadeira, energia metabolizável verdadeira corrigida.

Palavras-chave: coleta total de excretas, energia metabolizável aparente, energia metabolizável verdadeira, tamanho da partícula.

\section{REFERENCES}

Albino, L. F. T. (1991), Sistemas de avaliação nutricional de alimentos e suas aplicações na formulação de rações para frangos de corte. Viçosa. Tese de Doutorado em Zootecnia. Universidade de Viçosa, Viçosa, Minas Gerais, Brasil, 141p.

Blair, R., DAGHIR, N. J., PETER, V., TAYLOR, T. G. (1983), International Nutrition Standards for Poultry. Nutrition Abstracts and Reviews - Series B, 53, 669713.
Furlan, A. C. (1998), Valores Energéticos de Alguns Alimentos Determinados com Codornas Japonesas (Coturnix coturnix japonica). Revista Sociedade Brasileira de Zootecnia. 27 (6), 1147-1150.

Junior, A. A. F. (1998), Determinação dos Valores de energia Metabolizável de Alguns Alimentos Usados na Alimentação de Aves. Revista Brasileira de Zootecnia. 27 (2), 314-318.

Matterson, L. D., Potter, L. M., Stutz, M. W. (1965), The metabolizable energy of feed ingredients for chickens. Storrs. Connecticut. The University of Connecticut. Agricultural Experiment Station. 11p. (Research Report. 7).

Nascimento, A. H. (1998), Valores de Composição Química e Energética de Alimentos para Frangos de Corte. Revista Brasileira de Zootecnia. 27 (3), 579583.

NRC. (1994), National Research Council, Committee on Animal Nutrition. Subcommittee on Poultry Nutrition, Washington. EUA. Nutrient Requirements of Poultry. $9^{\circ}$. Ed. National Academy of Sciences. $155 \mathrm{p}$.

Rodrigues, P. B. (2001), Valores Energéticos do Milheto. do Milho e Subprodutos do Milho. Determinados com Frangos de Corte e Galos Adultos. Revista Brasileira de Zootecnia. 33 (6), 1767-1778.

Rostagno, H. S. (2005), Tabelas Brasileiras para Aves e Suínos; Composição de Alimentos e Exigências Nutricionais. $2^{\mathrm{a}}$ ed. Universidade Federal de Viçosa. $186 \mathrm{p}$.

S. A. S. Statistical Analisys System. (2000), User's Guide. 295p.

Shirivastav, A.K. (2002), Recentes Avanços na Nutrição de Codornas Japonesas. $1^{\mathrm{o}}$ Simpósio Internacional de Coturnicultura. Universidade Federal de Lavras. Lavras, p.6771.

Shirivastav, A. K. (1990), Effect of Dietary Calorie to Protein Ratio at Different Energy Concentration on Performance of Broiler Quails. Indian Journal of Poultry Science. 25, 79-87.

Silva, J. S. (2002), Análise de Alimentos: Métodos Químicos e Biológicos. Universidade Federal Viçosa. Minas Gerais, Brasil.

Vilar da Silva, J. H., Silva, M. B., Silva, E. L. Jordão Filho, Ribeiro, M. L. G., Costa, F. G. P., Dutra Júnior, W. M. (2003), Energia metabolizável de ingredientes determinada com codornas japonesas (Coturnix coturnix japonica). Revista Brasileira de Zootecnia. 32 (6), 1912-1918.

Zanotto, D. L., Brum, P. A. R. de, Guidoni, A. L. (1998), Granulometria do milho em rações para frangos de corte. Comunicado Técnico n⿳0 224. Concórdia - Embrapa, Centro Nacional de Pesquisa de Suínos e Aves, 2p.

Received: July 26, 2006; Revised: June 28, 2007; Accepted: September 10, 2008. 